\title{
SUSANNE LEVIN \\ An Example of Jewish Tradition Represented in a Literary Setting
}

\author{
Siv ILLMaN \\ Abo \\ $-\infty-$
}

\section{INTRODUCTION}

A literary work - a novel - is the focus of my presentation. My interest of research lies in the psychological aspects of religion and its diverse expressions in literary settings. In this type of study, the complexity of human beings, literature and the phenomenon of religion poses a real challenge.

The novel I have chosen is written by the Swedish author Susanne Levin, who was born in I950 in Uppsala, where she lives with her family. The story is also about a person born in 1950 and brought up within the tradition of Judaism in Uppsala, Sweden. In the story - told in a way which touches both intellect and emotion - we meet the fictive character Lea, as a child and then as a young woman confronted with difficult issues. We see anger and compassion at work, we encounter reaction to evil, we sense Lea's feelings of guilt, her gratitude, love, hatred, grief and joy. In addition, Lea's story gives a vivid account of life in a Scandinavian Jewish family from a time not so long ago. The interpretation will concentrate upon Lea's struggle to establish an independent and loyal personal life, in spite of conflict and tragedy. One major influence in Lea's life was the fact that her mother was a survivor from the Nazi death camps and had decided to keep silent about the terrible things in her past. This silence confused Lea significantly. Another tragic fact was that Lea as a young wife found out that she could never bear children of her own. In the novel, the impression is given that religion became an important factor in Lea's struggle. With the help of theory I will try to describe psychologically the role of religion in this process. 
Susanne Levin has written four novels so far, all of them portraying Jewish life in Sweden. The story about Lea is called Att leva vidare (To go on living) and this was published in 1994. The second novel, published in 1996, is called Som min egen (As my own) which is a continuation of Lea's story, primarily presenting the first years of her married life. The third novel from 1998 is a subtle description of negative attitudes to Jewish life and heritage in Uppsala in the I990s, with flash backs to the I920s. The title of this novel is at once challenging - Suggan $i$ domen (The Pig in the Dome) - hinting upon the medieval illustrations of pigs in some church buildings, which were seen to represent the Jews. In 2000 the novel Tillbaka till Király utca (Return to Király utca) was published.

Some premises and general guidelines for the study have to be discussed before I begin interpretation:

I. In my opinion, modern literary works, novels and poems often represent existential striving and religious experience sensitively and close to reality. This is why complex literary texts constitute an interesting and valuable source for the study of psychology of religion. Furthermore, there exists in the Nordic countries a research tradition using literary works and cultural products to learn more about the psychological aspects of religious experience. Methods of study have been elaborated along with theoretical description of the psychology involved.

2. Interpretation of psychology in literary works cannot as such be applied to the conditions of living persons, but literature can shed interesting light on empirical life and real people.

3. In a literary work, the literary aspects are important, of course, but a work of art can, through its concentration on the rules of art, express that which really highlights human experience. Such works describe what it is to be a human being, also suggesting an interpretation of life and, thanks to the aesthetic category, difficult things and elusive aspects of human striving get articulation. This is why the account of a literary work is sometimes felt to express matters more adequately than even strict historical documentation can. Thus, in essential literature readers can recognize questions, fears and hopes they deal with themselves, and identify with what is written, responding to it personally.

4. Thus, in articulating and interpreting complex situations and questions, the literary work fulfils important functions. This is significant, since many institutions which have traditionally formulated problems and provided orientation no longer do so. The world changes. Still, the fact remains that most people want to make sense of life. 


\section{METHODOLOGICAL QUESTIONS, THE PSYCHOLOGICAL PERSPECTIVE, DEFINITIONS}

On the whole, the study of the psychological aspects of religion expressed in a literary setting needs careful methodological consideration and tentative, interpretative approaches. In Susanne Levin's novel, for example, the aurhor's biography and fiction are certainly inflected. The author is represented in her text, in some way, but I do not look at such connections, the strictly literary aspects of the fiction, or religion as such. I study the text-immanent account of religion in order to identify the religiosity represented there, and to formulate an interpretation of the psychological premises and functions of this religiosity.

In this context, interpretation stands for a more or less meaningful understanding of the psychological aspects of religion and religiosity, and the formulation is related to theory. A literary work, like any work of art, actually demands many interpretations. Much remains to be said when any specific research perspective has been employed. For the sake of study, some reduction in method is necessary, even though the matter itself cannot be reduced. When it comes to defining religion, I start out with functional definitions so that, principally, anything in the literary description that could be of relevance, is included. Later, when one has learned more about the text's own consciousness of religion and seen the ways in which religion is expressed in the text, it is possible to be more specific about contents.

I relate the expressions of religion to the theoretical implications of a psychological model. This model contains elements and hypotheses which have to some extent been tested in neighboring empirical fields. To formulate the interpretation in relation to a given theoretical perspective is a useful method when the material consists of a literary text. This way theoretical context and a possibility to communicate the research process is provided, and to some degree this way the complexity of life striving, literary texts and religion can be respected.

The theoretical reasoning is developed within the framework of an integrated object relations perspective. ${ }^{1}$ This consists of several theoretical implications, from the theories of Melanie Klein, D.D.Winnicott and Fred C. Alford as well as modern perspectives on the psychology of religion. ${ }^{2}$ The basic view of reality underlying this theoretical perspective holds that human issues are related rather than isolated, and that "human conditions cannot be in just any fashion and still support life." 3 The model indicates that human beings are not just individuals, they are cultural and social beings as well, and people more or less all through life strive to relate meaningfully to reality. It is basically proposed that 
the drive to relate meaningfully to reality motivates the individual, and that it is influenced both by a person's own self consciousness, the life situation as a whole and by the values conveyed to the individual by a comprehensive point of view, like the ones represented by the meaning perspectives of religions.

Thus, religion is seen as an important potential and characterized as holding dimensions of experience of both very personal encounter character, and in relation to comprehensive meaning systems. It is argued, with the help of theory, that people tend to look to such comprehensive systems for orientation, and that communication with a worthwhile meaning system helps pave the way for a creative way of living. Furthermore, it is argued, that the meaning perspective of religion, for example, can activate a process which evokes new feelings and thoughts, and that development in relation to religion integrates values and ways, which change the view of reality. A cultural universe of significance is assumed to be worthwhile when it activates hope and motivates the individual to commit to life, alone and together with other people, in order to achieve common good and high goals.

The proposed, almost innate striving to relate needs re-adjustment from time to time, to keep the person's representations of reality up to date, within proportion and in touch with hope. In terms of theory, the inner frame of reference and human striving need cultivation in communication with comprehensive perspectives on reality, which convey, among other things, the notion that when you take responsibility for your self and for your relationships, also your sense of self-respect and belonging will be enhanced.

Psychic representations of reality, such as a person's self image and images of other people and God, are, according to theory, formed by a complex, continuous life experience. They gain their specific character from unique combinations of personality traits, culture and personal destinies and they color our perceptions and interpretations, and certainly or persuasions. Psychoanalysts and psychologists of religion (like Winnicott, Ana-Maria Rizzuto, Paul Pruyser, James Jones, David Wulff, Göran Bergstrand, Matti Hyrck) maintain, each in their own way, that people generally have a representation of God. Such a representation can be the "outcome of the child's relations with parents and other caretakers as well as of the child's (growing) interest in casual events" and in what is going on in a widening world outside the home, as well as the result of the working of the individual's self consciousness and reflection. Rizzuto, for one, states that whether or not the individual believes in that representation, it remains "potentially available throughout life." Whenever people try to get to the bottom of things to articulate, at least for themselves, their real feelings and thoughts these psychic 
representations are tested, and in such situations religion can become important.

In Susanne Levin's novel, religion is both a problem and a resource. I have identified a creative process describing how the fictive character connects with religious tradition in a new way. In interpretation the account of this is compared to an integrated theoretical construct emphasizing the relational structure of human life and pursuit. I use such a theory rather than for example Freudian or Jungian theories on religion. Freud and Jung know about the human psyche and its ways of functioning, but when it comes to religion they reduce and generalize and give religion a one-sided description. Freud's interpretation of transference and transcendence leads to the conclusion that religious commitment is a sign of pathology. Jung's theory attributes religion a natural place in human existence in a life-cycle perspective, and sometimes sees religious conviction as a sign of health, sometimes as a symptom of illness, but it generalizes the realm of experience of "the Sacred" at the expense of significant historical and external factors. ${ }^{5}$

The term religion, is used to designate a general aspect of the phenomenon. In Lea's story, religion refers to Judaism. The term religiosity or religious experience stands for an experiential, internalized and somehow personally committed relating to religion. ${ }^{6}$

I will try to show how religion is given expression in the text, mainly by focusing on how inner representations are influenced in the process when external difficulty, inner conflict and imperfection get worked through in relation to religious tradition and reality as a whole. This experience of one's relationship to God, or to ultimate reality, makes a difference, and the potential for change is thought lie in the kind of God image which evolves when the person relates himself or herself to God as the "You" of religious tradition. Religious experience in this context means the experience of significance, centered around experiençing the presence of God, and - depending on the human situation - around relating to the meaning perspective of religion. The theoretical perspective emphasizes that all that is important takes place within relationships - also when it comes to religion, that religion provides views on what it is that makes human ambition worthwhile and authentic, and that the primary psychological function of the God image (imago) in a process of crisis and development leading to gratifying solutions, lies in its potential to effect change in the individual person's world of experience. At best, religion helps pave the way for processes of integration and it opens the person to the world. 


\section{AN ILLUSTRATION OF THE INTERPRETATION \\ OF THE PSYCHOLOGY OF RELIGION IN THE NOVEL}

With these theoretical implications I now turn to the story itself. It is clear that Lea was faced with constant pressure. She protested against iniquity and she tried to fight helplessness. The Holocaust and Judaism appears as especially troublesome constituent realities of her own existence. But, in the process, a new modus vivendi evolved. Lea could go on living, since significant elements of reparation and recreation gradually became part of herself, providing her with a new sense of self-respect and belonging, motivation and hope. The external circumstances remained much the same, difficult things remained difficult, but on the inside something had changed, a specific sense of guilt ceased to afflict Lea's mind and she could look forward with genuine expectation. Lea worked through her difficulties in the immediate encounter with her own reality, and her actions, behavior and reflections show that a new way of assessing self-affirmation, transference and transcendence grew out of her experience.

It is also clear that Lea is a complex person, resolute, not typically pious, and determined to analyze her life situation. But her striving to do something about her life situation was filled with mixed feelings - of love and revenge, of hatred, especially for Hitler who had killed so many Jewish children. She was also angry at her mother, and felt betrayed while she had not tried to explain about the terrible things which still affected life. Lea's father came from a Jewish family which had lived in Sweden for many generations. He "knew" how Jews should live in the country, whereas Lea's mother did not know, making her feel insecure and subjected. For various reasons Lea was disappointed with her father, too, but she also loved him. Most of all Lea was displeased with herself and distraught. But, together with her negative feelings and destructive thoughts, she carried on a strong vision of a good life, which she wanted to realize for other people as well as for herself. An element of this vision was her strong ambition to give life to many Jewish children, to "replace" those who Hitler had murdered. This ambition was born out of the passionate love and hatred of a young child and this conviction was carried on in much the same shape into adult life. She wanted to help maintain Jewish life and tradition. However, the perspective became impossible to reconcile. Lea had to have an operation because of some painful internal "inflection" in her body. The operation left a scar, similar to the one she was told her Hungarian grandmother had had. The resulting infertility was deeply afflicting, a tremendous loss, a wound in Lea's existence, a blow to her femininity, a painful void in her body. Lea was also left with the feeling that she had definitely 
failed her mother -and all Jewish mothers and that she had let Hitler win again, this time over herself.

In her effort to cope, Lea came to reflect on the women of the Bible and of the women she was related to in the generations before her own, and she began to feel close to them, to see herself as one of them. Her own self-consciousness and the world around her activated thoughts and feelings, and through all kinds of experiences new perspectives were presented to her, through the symbols and ceremonies of tradition and culture, encounters with other people, objective realities and mere chance. The symbols of religion helped bridge conflicts and gave comforting as well as challenging new visions to Lea. Significant interpersonal experiences had similar balancing functions. An example of this is given in a passage where Lea's interaction with one of her many unmarried aunts is described. Lea was worried sick for this elderly lady. She was special to Lea, and now she had been run over by a car. The manner in which Lea reflects on this accident and on her aunt's attitude to it, gives an idea of where the key to Leas own solution lay. Within the framework of a significant and warm relationship, meaning was developed. Lea was amazed by the calm her aunt expressed although she had almost died in the accident. The lady had lived to help disabled persons and just barely survived and became a convalescent. When Lea had asked her aunt about the "meaning of it all", the answer was (I quote): "Yes, you see, I have worked all my life to help people out, for example after accidents like this one. Maybe it was meant for me to get to experience how it is from the inside (my marking), if you see what I mean." - This passage describes not only the aunt's attitude to the accident, but also Lea's new understanding of her own "life accident" - both the trouble with her mother's Nazi experience and with the fact that she could not bear children, a fact that received ultimate aspects in the light of the Shoah. In working through her situation, Lea related herself to ultimate aspects of life and tradition, and this relation provided a transitional field of experience in which her basic patterns of relating and making sense of experience were influenced. Here unspeakable conflict and pain could be expressed, displayed and given proportion.

From a psychological point of view, Lea experiences that the God of tradition was somehow different, not what she had previously thought God to be. A shift in Lea's image of God or of her comprehension of what is ultimately true and worthwhile, parallels the shift in Lea's self image and in her relationships to other people, as well as to the whole of reality. Such relationships introduced Lea to a new way of looking at life. This time her connection to religion took place from a realistic basis in herself, and it meant encounter with an autonomous counterpart which was considered capable of serving 
both as a trustworthy, ultimate refuge and as an objective perspective on what is worth striving for in life. Thus, the implication is that what came to represent God to Lea, in the process of relating to life, was included in a more comprehensive image. It included both evil and love.

The interpretation that Lea's inner representation of God changed, and that this changed image of God constituted the potential for change in Lea herself, is reflected in many instances in the novel. The God of "Abraham, Isaac and Jacob" also becomes Lea's God, so to say. For Lea, a dark, weak or inscrutable side of God was represented by the Holocaust. The conflicting feelings and thoughts contained in this representation of God were consciously brought to mind, and a real testing of God took place. The absconditus aspect of God was analyzed also when Lea reflected on her mother's silence about the Shoah and her own reaction to this. Another struggle with God went on in Lea's efforts in coping with her existential accident - the inability to produce Jewish babies. In addition, the absconditus aspect was activated in Lea's prevailing experience of threats to life, to her mother - to Lea. In light of all the lost Hebrew children, and in light of Lea's infertility, her loss was unconditional. Thus, in a way, Lea became a "witness" herself to annihilation and one of those who have suffered great loss and who have loved much.

Quite another side of God was familiar to Lea from early on, that is God as "the Lord of the Sabbath". For Lea, both grace and high holiness were connected to this image, both female authority and male dignity, but it harboured conflict and opposition, too. In the testing an understanding was found, according to which God's mercy and majesty were no longer conflicting interests, but qualities which were felt to continue to exist fully in reality. In this way, Lea's representation of God was consciously experienced and new aspects of reality were integrated in the mind and contained in a more cohesive image of God, which now, intellectually and emotionally, was a more agreeable image of God.

Another way of describing that Lea's image of God became more complex and "holding" can be implicated from the way the image of God "the Lord of the Sabbath" also came closer to Lea's notions of God as the "the God of the Ten Commandments". This is indicated in the way Lea combines God as an instance who "ultimately" sanctifies people by giving them commandments, which by quality and intention preserve, maintain and recreate life, with God as the Lord of the Sabbath who says: "light candles!" The same integrated view of God as the mighty and merciful God who once liberated the Jews from Egypt's darkness is implicated when God of the Ten Commandments, who says "I am the Lord, your God!" is also experienced as the Good Shepherd, who orients in life and provides for life. 
From a psychological view, the combination of comforting and stimulating factors in what is representative of God, makes this image function as an activating and good "ego ideal". Here the image of God signals departure and change as necessary conditions for sustainable existence.

The emergence of a more cohesive and coherent view of God basically meant that the God of tradition who had existed long before and independently of Lea, now was close in a new way and still genuinely transcendent. Something about Lea's experience of God's presence can be interpreted from her reflection on symbols and rites, on events and persons in the immediate situation, on experiences in her own mind and body. Religion as described in the story, seems to be at times represented to the individual on the level of common creed, shared rites and traditions, and at other times through personal experience, and the various dimensions of religion seem to co-exist well. From a psychological point of view, the complexity of the representation of God and the flexibility of the ways of connecting to religion, illuminate and emphasize the need for creative change throughout life. The emerging representation for God stands for an "object relational" partner with the capacity to motivate change. And God is even implicated as the one who "goes in advance", not just as the Commander in Chief, but as one who goes before all others into the unknown, into darkness, into serious self examination - almost like the High Priest on Yom Kippur who atones on behalf of "all people". Thus, the assurance "I am the Lord, your God" can mediate hope and brave encouragement. The message that God cares and that God sanctifies human beings by challenging them is transmitted to those who need it. The element of suffering present in Lea's story makes it plausible to include an aspect of God as the one who suffers with people in pain and calls them to "light candles". Also, the ontological statement "I am" referring to God can be interpreted to stand for a positive absconditus aspect, like the statements of so called negative theology or apophatic theology, according to which God is semper major, always greater and different from what words can express. From a psychological view, the statement "I am" about God can function as a very strong affirmation on the anthropological level, for the human subject.

Lea's process of internalizing a more wholesome image of God was mediated, also by the fact that her Gentile husband had promised to let their future children be raised in the Jewish tradition, and reading Elie Wiesel's book The Night meant much to Lea. His book deeply moved her and opened her eyes to new aspects of the survival perspective. She could identify with the feelings and thoughts expressed in the text. Her own world of experience had been articulated, and her own pain and distress had been formulated. And Wiesel who had himself seen what really happened to small children in the camp, 
also envisaged a way to come to grips with this cruelty and one's own hateful and crippling reactions to this.

An interpretation of Wiesel's book along similar lines is pointed out by Robert McAfee Brown, ${ }^{7}$ who identifies a process going "from repudiation of hatred to affirmation of anger" in Wiesel's works. Hatred is, "almost through grace" changed into anger, which is something people can deal with. It can "provide drive for humanitary purposes and for faith." According to McAfee Brown, grace in Wiesel's context stands for other people - people who "witnessed", saw through what happened, listened and stood by. ${ }^{8}$ The presence of "the other", concretely or in a moral sense, represented hope, thereby making life possible again - "with and on the ruins" (Wiesel).

To Lea, the reading of Wiesel's book meant recognition and a touch of belonging, a sense of correspondence. This helped balance her own situation. Lea was pleased that Wiesel did not reduce cruelty nor goodness, and that he pointed out a possible way to live with imperfection and opposition. His book suggested to her that resolution is found when one becomes a witness oneself - a messenger - out of respect for oneself and for living life. Also, Lea's interpretation of Wiesel shows the influence of new aspects in her image of God. Wiesel probably inspired Lea to become an author herself to maintain Jewish values and ways. Susanne Levin's book starts with a few lines quoted from a poem by the Swedish poet Hjalmar Gullberg, ${ }^{9}$ which can be interpreted as referring to the work of an author. The lines suggest literary writing as a means of contributing to life and of finding the "right words". Only the right words offer shadow. They are like a tree with a mighty crown harboring singing birds.

\section{Concluding words}

Consciously, the thought of becoming an author herself came to Lea when she was resting after the operation in the clinic. In the morning of that day, Lea had said the Shema Israel and decided to put herself into God's hands. When reflecting also on her grandmother who had had a similar operation, Lea thought that maybe she herself, in spite of all, had an inner place left, from which to contribute to life and her own well-being, although much of her womb had been removed. By producing and interpreting in her own "inner existence space" ${ }^{10}$ symbols and words related to her own reality, her culture and religion, she would be able to share Jewish values in a personally gratifying way. 
In a novel like this Jewish life and theology are linked together in a psychologically interesting way. Lea's basic striving to live a creative life was "cultivated" in communication with other people and collective views on life, and with the symbols of religion. This interplay gave her self-respect, space and hope.

In this respect the novel reminds me of the words by which Gösta Lindeskog once characterized Jewish theology. He pointed to the fact that Jewish theology

while it gathers its strength from the ancient fountains, at the same time interprets in the light of experience the fundamental Jewish ideas of religion in an individual, creative way. ${ }^{11}$

\section{Notes}

I. S. Illman, Vere adest. Religionspsykologisk tolkning av närvarotemat i Olov Hartmans romaner. Åbo Akademis förlag: Åbo 1992.

2. The theoretical thinking contains implications from Melaine Klein's thought, from Donald W. Winnicott on transitional phenomena and arguments from C. Fred Alford's philosophical interpretations of narcissism.

3. S. Illman, Response, in: J.Neusner (Ed), Religion and the Social Order. Scholars Press, Atlanta: Georgia 1994, 264

4. David M. Wulff, Psychology of Religion. Classic and Contemporary. Second Ed. John Wiley \& Sons, Inc.: New York etc 1997,343

5. James W. Jones, Contemporary Psychoanalysis and Religion. Transference and Transcendence. Yale University Press: New Haven r99x.

6. Pargament's definition: Religion is found at the junction of two large spheres: the sacred and significance. In more social-scientific language: religion involves a particular substance with a particular function. I define religion as a process, a search for significance in ways related to the sacred Kenneth I. Pargament, The Psychology of Religion and Coping. Theory, Research, Practice. The Guilford Press: New York, London 1997, 32.

7. R.McAfee Brown, Messenger to All Humanity. London: University of Notre Dame Press. Notre Dame (Indiana), I983, 20r. The author: hatred is no solution to suffering; going through hatred, contempt, Wiesel ended up with creative anger.

8. See the Prayer in E.Wiesel, One Generation After. Schocken Books: New York I982, 198

9. "Bara de riktiga orden,/ orden med krona och fågel/sång har en skugga som träden." Hjalmar Gullberg.

Io. N.G. Holm, "Religious Symbols and Role Taking", in: N.G. Holm / J.A. Belzen (Eds), Sundén's Role Theory - an Impetus to Contemporary Psychology of Religion. Religionsvetenskapliga skrifter 27. Åbo: Åbo Akademi Press, 1995, I29-145

II. G.Lindeskog, "Judaism Today", in: G. Hedenquist (Ed), The Church and the Jewish People. Edinburg House Press: London 1954, 5 


\section{SAMMANFATTNING}

Artikeln presenterar en religionspsykologisk tolkning av romanen Att leva vidare (Natur och Kultur 1994) av Susanne Levin. Romanen beskriver hur en ung, svensk judinna, Lea, född på r950-talet, på tröskeln till vuxenlivet tvingas bearbeta sina relationer till omvärlden, sig själv och den judiska traditionen, inte minst Holocaust som har följt henne sedan barndomen genom att hennes egen mor är en överlevande. Den skönlitterära skildringen väver samman existentiella och religiösa strävanden på ett psykologiskt intressant sätt och artikulerar viktiga frågor och svar. Ett integrerat objektrelationstänkande impliceras som teoriperspektiv för den psykologiska tolkningen av den skildrade religositeten. Resonemanget inbegriper aspekter från teorierna hos Melanie Klein, D.W.Winnicott, C. F. Alford och från nyare religionsvetenskapliga sätt att se på upplevd religion. Materialet är av den arten att man måste ringa in religiositeten funktionellt att börja med, sedan prciseras den närmare och tolkas med hjälp av teorimönstret. Tesen går ut på att uppgörelserna aktiverar förändringar och att omställningarna ifråga om gudsrepresentationen har stor betydelse och katalyserar förändring som ger motivation och hopp. I processen aktualiseras kommunikationen mellan innersta och yttersta verklighetsaspekter. Artikeln argumenterar för att väsentliga skönlitterära verk, som är ett speciellt material för religionspsykologin och ställer speciella krav på metoderna, ger meningsfulla uppslag om religionens psykologi. 